\title{
Evaluation of Teaching Environments Created by Pre-service Science Teachers ${ }^{\mathrm{i}}$
}

\author{
Ebru Altun ${ }^{1, *}$, Tuncay Özsevgeç ${ }^{2}$ \\ ${ }^{1}$ Faculty of Education, Recep Tayyip Erdogan University, Turkey \\ ${ }^{2}$ Fatih Faculty of Education, Karadeniz Technical University, Turkey
}

Copyright $(2016$ by authors, all rights reserved. Authors agree that this article remains permanently open access under the terms of the Creative Commons Attribution License 4.0 International License.

\begin{abstract}
The aim of this study is to examine teaching environments that prepared and performed by pre-service science teachers in order to determine characteristics of these environments and conformity of these environments with referred to argument driven inquiry. In this context, micro teaching practices performed by the participants were observed and recorded for 10 weeks. Data obtained from 31 followed groups were examined with content analysis. According to results of the analysis, it can be said that all of the groups defined the concepts and partially made statements to reveal relationships between the concepts, while evaluation between concepts could rarely be made by means of activities that allow reaching a common judgment. Considering the teaching environments referred to argument driven inquiry, it can be suggested that revealing the relationships between concepts and performing the evaluation process is more appropriate than making definitions of the concepts. Also it was found that throughout univocal-descriptive dialogues often took place in practices. In addition, it was found that triadic dialogues which based on initiate-respond-evaluate/feedback [IRE/IRF] often were used during practice, pre-service teachers finished the chain at that point not asking follow-up questions for eliciting in-depth knowledge.
\end{abstract}

Keywords Argument Driven Inquiry, Teaching Practices, Pre-service Science Teacher

\section{Introduction}

The inclusion of argument generation and evaluation skills on such high profile indicators implies that they are necessary components for success in life in the $21^{\text {th }}$ century [1]. From a general perspective, it is seen that arguments of the individuals remain unjustified, incomplete or incorrectly configured and individuals have difficulty in creating proper arguments [2, 3]. In 2011 National Research Council published a new framework for K-12 Science education and identifies eight scientific practices such as asking questions, developing and using models, planning and carrying out investigations, analyzing and interpreting data, using computational thinking, constructing explanations and engaging in argument from evidence. According to National Research Council [4], by the end of $12^{\text {th }}$ grade all students should be able to engage in productive discussions about, and make informed decisions on, science related issues as well as be " critical consumers of scientific information". For realization of these goals, it is very important that teachers support and guide students through appropriate activities. The ability to guide classroom discussion and control the flow of discourse is the hallmark of effective science teachers $[5,6]$.

In learning environments, students may experience problems in areas such as observing, predicting, saving data, using data and modelling, data interpretation, inference, hypothesis and experimental design. In this case, teachers are required to involve students in the process. This process can be prompted with questions such as, "What are you going to do next?" "What outcome do you predict?" "What did you learn?", "How do you know?" by teachers [5]. Integration of these types of questions into the learning environment can promote students with issues such as asking questions, supporting their arguments with objective data, description of the rationale, and assessment of alternatives. It is important that teachers have knowledge, skills and experience about promote effective learning in science, integration of argumentation in science lessons, support student to engage in argumentation, manage learning process successfully [7, 8, 9]. According to the literature, it can be said that teachers and most pre-service teachers lack opportunities to participate in activities involving scientific inquiry in the learning stages $[5,10,11$, 12]; hence, they are unable to develop their skills in this area. In order to eliminate such inefficacy, teachers should gain competence in this field before starting their professional life or career. Teachers in the profession can acquire these qualifications through their own efforts or in-service training. Not all teachers who have just obtained undergraduate 
degree may have the time or opportunity to develop these skills. Therefore, it is important to try to develop these skills, especially in the undergraduate education. In this scope, revision could be made on elective or compulsory courses offered to pre-service teachers throughout their undergraduate education, or other elective courses could be included in the curriculum considering these skills.

The aim of study this study is to examine the micro-teaching practices prepared by pre-service science teachers in relation with specific attainments and performed with their peers in order to evaluate characteristics of the learning environments they create in the context of argument driven inquiry.

\section{Method}

Study group is comprised of pre-service science teachers a state university in the Eastern Black Sea Region of Turkey. In course named "Science Teaching Laboratory Practices I", pre-service teachers were divided into groups. Each group is composed of two teachers corresponding to a total of 33 groups. Although a total of 33 groups were formed in the study, study data could be obtained from 31 of them because 2 groups did not perform the micro learning practices. Each group was given different attainment of national science curriculum. Some of these attainments like as:

- able to discuss the observations regarding the structure of the cell by from past to present by associating with technological developments.

- able to substances understand that matter has a granular, porous and movable structure.

- able to develop alternative heat insulation materials.

- able to explore and present the effects of using different types of fuel for heating on humans and the environment.

- able to experimentally compare the density of liquids insoluble in each other.

The groups prepared lesson plans and different activities in connection with the respective attainment they were given. They were given the enough time to prepare the lesson plans and activities. Micro teaching practices were conducted with their classmates in their class. This was followed by evaluation of the micro-teaching practices and giving of feedback by their classmates. The micro-teaching process was applied in the same way for all groups. The researcher recorded micro teaching practices of pre-service teachers during lessons. Data collection was completed in 10 weeks.

\subsection{Data Collection Instruments}

During the fall semester of 2013-2014 academic year, pre-service science teachers were observed during the "Science Teaching Laboratory Practices _ I" course for 10 weeks to collect data. Before starting the observations, researcher briefed the participants about the study to be carried out and variables to be investigated in the course and then obtained their consent for voice recording. In this process, researcher simply assumed the role of observer. There was no impact to the direct micro teaching practices.

Observation was performed to examine the learning environments created by pre-service science teachers according to an attainment [s], to identify the roles assumed by pre-service teachers, their discourses and questions and in-class interactions with the ultimate aim of checking conformity of their existing status. In this context, pre-service teachers created groups of two and designed various activities related to the attainment[s] in the science curriculum and performed micro teaching practices accordingly.

Besides observations, voice recording was made in 31 groups that performed presentations. All of the recorded micro teaching practices were transcribed. The four transcribed micro teaching practices were analysed by two researchers together to determine meaningful data units and make coding, in the light of the problems of the research. Then, other transcriptions were separately analyzed by the researchers. After analysis of all transcripts, researchers investigated the consistency between the codes and themes together. To find out the interrater reliability of two experts, Cohen Kappa coefficient was calculated, it was 0.75 and it indicated agreement at a significant level. Then, tables were prepared to fit the purpose of the research by using the codes and themes.

In line with the aim of this study, certain themes were compiled from the literature such as explanation, description, evaluation, questioning, exemplification, and arguing to take a picture regarding how pre-service teachers configure the implementation process.

These items were examined in the context of the meanings given in the Great Turkish Dictionary by Turkish Language Association [13]:

Explanation: 1. To highlight a concept or case by revealing links between its items after resolving. 2. To put forward not only what is but also the cause; to show the causal connection between two things.

Evaluation:1. The conclusive result reached by researching the quantity or quantity of something. 2 . Stating the importance of similar events according to some measurements. 3. Measuring in different ways the realization rate of various teaching purposes, and appraising on resulting findings.

Arguing: Mutual defence of opposing thoughts, to persuade by reasoning

Description: To explain a concept entirely with all the elements, to introduce or describe a person or object by listing their special and immutable characteristics.

Exemplification: To show an object, condition and process through samples.

In order to examine the talk moves used by pre-service teachers during the implementation, the scheme introduced by Boyer [5] was taken as a basis. In this scheme, talk moves were evaluated under six different topics. 
Table 1. Talk moves [5]

\begin{tabular}{cccc}
\hline Forms & Codes & Examples & Suggestions for use \\
\hline Re-voicing & A1 & $\begin{array}{c}\text { So let me see if I've got your thinking } \\
\text { right. You're saying........? }\end{array}$ & $\begin{array}{c}\text { Clarifying student through and reinforcing ideas for } \\
\text { the rest for the class }\end{array}$ \\
\hline $\begin{array}{c}\text { Asking students to restate } \\
\text { someone else's reasoning }\end{array}$ & A2 & $\begin{array}{c}\text { "Can you repeat what he just said in your } \\
\text { own words?" }\end{array}$ & $\begin{array}{c}\text { Allows students to reflect on what they do and do not } \\
\text { understand. }\end{array}$ \\
\hline $\begin{array}{c}\text { Asking student to apply their } \\
\text { own reasoning to someone } \\
\text { else's reasoning }\end{array}$ & A3 & "Do you agree or disagree and why?" & $\begin{array}{c}\text { Make student more aware of discrepancies between } \\
\text { their own thinking and that of others [including the } \\
\text { scientific community.] }\end{array}$ \\
\hline $\begin{array}{c}\text { Prompting students for } \\
\text { further participation }\end{array}$ & A4 & "Would someone like to add on?" & $\begin{array}{c}\text { Allows students to reflect on, participate in, and build } \\
\text { on scientific thinking. }\end{array}$ \\
\hline $\begin{array}{c}\text { Asking students to explicate } \\
\text { their reasoning }\end{array}$ & A5 & $\begin{array}{c}\text { "Why do you think that?"or "What } \\
\text { evidence helped you arrive at that } \\
\text { answer?" or "Say more about that." }\end{array}$ & $\begin{array}{c}\text { Improve students' ability to build scientific arguments } \\
\text { and reason logically. }\end{array}$ \\
\hline Using waiting time & A6 & "Take your time... We'll wait." & $\begin{array}{c}\text { Increase participation in a discussion by allowing } \\
\text { students to think about their ideas. }\end{array}$ \\
\hline
\end{tabular}

Analysis of discourse pattern is important to evaluate learning environment which organised by pre-service science teachers. Patterns of discourse are analyzed by Harlow and Otero's [14] four-stage model.

1. Univocal-Descriptive: This stage is characterized by the teacher eliciting knowledge from the students. The teacher did not probe for further explanation from the students and students did not converse with each other. All conversation either came from or was directed toward the teacher. This initial stage of the conversation began when the teacher asked an open ended question, attempting to elicit knowledge gained about subject.

2. Univocal-Model Identification: In this dialog type, there are a teacher and one student. The teacher asking one more questions to a student in that eliciting knowledge from student deeply.

3. Dialogic-Model Establishment: This stage involved a repeated exchange between two students making I think statements and establishing their models.

4. Dialogic-Model Discussion: In this stage, other children entered the conversation and the children further articulated and supported their viewpoints. Stage four in our model began when the researcher stepped in to explain that two models of current flow had been proposed by the students [14]

\section{Results}

Themes were created regarding in-class interactions to depict how pre-service teachers plan the practice.

Analysis of the practices performed by the participants is given in Table 2 .
As one examines the table, it can be seen that many groups could not put forth the concepts related with the attainments in connection with the other concepts during their practices, but they could just provide descriptions. Some other groups linked related concepts with the other concepts during presentations and evaluated this relationship from different aspects [G4, G7, G10, G11, G13, G14, G15, G16, G17, G20, G26].

During practices, pre-service teachers often asked questions to the other peers and listened to their responses. Still, the interaction remained as a one-way univocal student-teacher dialogue. This type of dialogue is far from creating a general argument driven inquiry where all class members take part. Only few of the groups [G4, G5, G11, G15, G17, G27] were able to create a dialogue based on dialogic interaction..

In practices performed by pre-service teachers, as dialogues were usually in the form of univocal, feedback was given as correct or wrong answers. During the practices, often triadic dialogue took place in the form of initiation-respond-evaluation/feedback [IRE/IRF] while ignoring additional related questions to set out deeply the existing knowledge or reveal the issue in more detail. Group 27 addressed additional questions to consolidate the discussion and ensure interaction during practice. Apart from that, some groups [G1, G5, G11, G14, G15, G17] were seen to ask further questions departing from answers of the questions asked in certain parts of the practice. During practices, frequent use of initiation-respond-evaluation/feedback dialogue prevented starting of discussion. Throughout the process, a dialogic interaction could hardly be achieved with the help of additional follow-up questions departing from students' responses. 
Table 2. Teaching Strategies and patterns of discourse which are used through teaching practices

\begin{tabular}{|c|c|c|c|c|c|c|c|c|c|c|}
\hline \multirow[b]{2}{*}{ Group number } & \multicolumn{6}{|c|}{ Teaching Strategies } & \multicolumn{4}{|c|}{ Patterns of Discourse } \\
\hline & Description & Explanation & Evaluation & Questioning & $\begin{array}{c}\text { Exemplificati } \\
\text { on }\end{array}$ & Arguing & Univocal- descriptive & $\begin{array}{l}\text { Univocal- model } \\
\text { identification }\end{array}$ & $\begin{array}{c}\text { Dialogic-model } \\
\text { establishment }\end{array}$ & $\begin{array}{c}\text { Dialogic-model } \\
\text { discussion }\end{array}$ \\
\hline 1 & ++ & + & - & ++ & ++ & + & ++ & + & + & - \\
\hline 2 & ++ & + & - & ++ & ++ & - & ++ & - & - & - \\
\hline 3 & ++ & - & - & ++ & - & - & ++ & - & - & - \\
\hline 4 & ++ & + & + & ++ & - & + & ++ & + & + & + \\
\hline 5 & ++ & + & - & ++ & 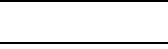 & + & ++ & + & + & + \\
\hline 6 & ++ & + & - & ++ & + & + & ++ & - & + & - \\
\hline 7 & ++ & + & + & ++ & ++ & - & ++ & - & - & - \\
\hline 8 & ++ & + & - & ++ & - & - & ++ & - & - & - \\
\hline 9 & ++ & + & - & ++ & - & - & ++ & - & - & - \\
\hline 10 & ++ & + & + & ++ & - & - & ++ & - & - & - \\
\hline 11 & ++ & ++ & + & ++ & ++ & ++ & ++ & + & + & + \\
\hline 12 & ++ & - & - & ++ & - & - & ++ & - & - & - \\
\hline 13 & ++ & + & + & ++ & - & - & ++ & - & - & - \\
\hline 14 & ++ & ++ & + & ++ & ++ & + & ++ & + & + & - \\
\hline 15 & ++ & ++ & + & ++ & ++ & ++ & ++ & + & + & + \\
\hline 16 & ++ & + & + & ++ & - & - & ++ & - & - & - \\
\hline 17 & ++ & + & + & ++ & ++ & ++ & ++ & ++ & + & + \\
\hline 18 & ++ & + & - & + & - & - & ++ & - & - & - \\
\hline 19 & ++ & + & - & ++ & - & + & ++ & - & - & - \\
\hline 20 & ++ & + & + & ++ & ++ & - & ++ & - & - & - \\
\hline 21 & ++ & - & - & ++ & + & - & ++ & - & - & - \\
\hline 22 & ++ & + & - & ++ & ++ & - & ++ & - & - & - \\
\hline 23 & ++ & + & - & ++ & - & - & ++ & - & - & - \\
\hline 24 & ++ & - & - & + & + & - & ++ & - & - & - \\
\hline 25 & ++ & + & - & ++ & - & - & ++ & - & - & - \\
\hline 26 & ++ & + & + & ++ & + & - & ++ & - & - & - \\
\hline 27 & ++ & + & - & ++ & ++ & + & ++ & + & + & ++ \\
\hline 28 & ++ & - & - & + & - & - & ++ & - & - & - \\
\hline 29 & ++ & - & - & + & - & - & + & - & - & - \\
\hline 30 & ++ & - & - & ++ & - & - & ++ & - & - & - \\
\hline 31 & ++ & + & - & + & - & - & + & - & - & - \\
\hline
\end{tabular}

[++ Observed throughout the micro teaching process, + Observed during certain parts of the micro teaching process, - Not observed throughout the micro teaching process] 
During the practices, also talk moves addressed by pre-service teachers to their peers were identified. The table displaying talk moves asked in this regard is seen below:

Table 3. Talk moves which are used through teaching practices

\begin{tabular}{|c|c|c|}
\hline Forms & Code & Groups \\
\hline Re-voicing & $\mathrm{A} 1$ & $11,19,26,27$ \\
\hline $\begin{array}{l}\text { Asking students to restate } \\
\text { someone else's reasoning }\end{array}$ & $\mathrm{A} 2$ & - \\
\hline $\begin{array}{l}\text { Asking student to apply } \\
\text { their own reasoning to } \\
\text { someone else's reasoning }\end{array}$ & A3 & 27 \\
\hline $\begin{array}{l}\text { Prompting students for } \\
\text { further participation }\end{array}$ & A4 & $\begin{array}{c}1,2,3,4,5,6,7,8,9,10,11 \\
, 12,13,14,15,16,17,18, \\
19,20,21,22,23,24,25, \\
26,27,28,29,30,31\end{array}$ \\
\hline $\begin{array}{c}\text { Asking students to } \\
\text { explicate their reasoning }\end{array}$ & A5 & $\begin{array}{c}1,5 *, 11 *, 14,17 \\
22 * 26 *, 27 * \\
\end{array}$ \\
\hline Using waiting time & A6 & $\begin{array}{c}1,2,3,4,5,6,7,8,9,10,11 \\
, 12,13,14,15,16,17,18, \\
19,20,21,22,23,24,25, \\
26,27,28,29,30,31\end{array}$ \\
\hline
\end{tabular}

*: "why" and "how" questions were asked only during some parts, not entire of the practices.

The table shows that different types of talk moves were used by all groups to increase the participation of students. After teachers obtained responses from the students, they often used interrogative patterns such as "Does anybody else want to answer?" and "What else could it be?" They were followed by assessment of the responses. Besides this, waiting time was given to all groups for their responses. None of the groups used questions at A2 level for repetition of the answers. Similarly, questions at level A5 which require justifications were used by few groups only, even not during the entire practice.

\section{Discussion}

It is one of the mechanisms which will bring the change to understand the world, to make sense of it, make inquiries to assess phenomenon, to present their ideas, to stand behind their ideas and attempt to defend them ultimately evaluating the alternatives to achieve general acceptance along with others. Individuals find solutions and general acceptance by means of discussion. This might be the case in issues related with education as far as social issues. In order to achieve the best, it is necessary to eliminate the alternatives with reasonable grounds. The purpose of the educational curricula is to provide the best training for students in the most plausible and reasonable way. As we switch from education to science education as a more specific area, this aspects gain even further importance. Therefore, educational curricula are constantly updated to meet the requirements of the age. In particular, the curriculum for science education was updated in 2013 in Turkey. Now it places particular emphasis on inquiry and arguments revealing the necessity to transfer these elements to the educational environments.
At schools, it is observed that learning environments built on argumentation are not provided at desired level [15, 16, 17], sometimes teachers could not answer different types of questions which might come from students in the overall process, and mostly they react as telling them to search for the answer instead of answering their questions. Due to the function of teachers as role model for both mental and social development of students, it seems sensible to expect teachers to demonstrate their proficiency in creating argumentation-based learning environments and guiding students in this process.

While assessing the micro teaching practices of the pre-service teachers, different categories were used such as teaching strategies, patterns of discourse and talk moves. Investigation of the teaching strategies used by the participants is important because continued use of definitions of basic science subjects, not mentioned relationships between different concepts or continuously giving of similar examples in learning environments might lead to a traditional classroom environment. In fact, students would gain more benefits from the learning environments where the causal link between different concepts can be seen by establishing cause and effect relationship between these concepts, or by creating a learning environment based on argumentation on different topics, and where alternatives are evaluated by using the justifications. The teaching strategies and speech acts used by the per-service teachers also directly affect the discourse taking place in class.

From this point of view, the findings obtained from this study could be leading. It was seen that all of the groups could define the concepts specific to the attainments, provide partial explanations for relationships between the concepts, whereas they could seldom run activities to help reach common judgement and make evaluations in relation with concepts. Considering the references to generating argument-based learning environments, it seems sensible to realize the evaluation process whereby relationships between concepts are demonstrated rather than providing definitions for certain concepts in the learning environments. Teachers cannot simply focus on explaining the theories, laws, models, and unifying concepts of the various disciplines if they want to help student learn how to participate in scientific argumentation [17].

Besides, the activities performed during in-class activities reveal that univocal-descriptive dialogues based on teacher-student interaction often take place almost leaving out dialogic interactions based on teacher-student and student-student dialogues, which is desired in contemporary science classes. In argumentation-based learning environments, dialogic interaction is very important. It is necessary to construct the knowledge in a collaborative manner by means of interaction, to put forward arguments for answering the questions concerning the existing problem, and to match such arguments. It is very difficult to create a rich discussion and inquiry environment with teacher-to-student interaction only. Moreover, it was found out during practices that triadic 
dialogues in the form of initiation-respond-evaluation/feedback were often employed by pre-service teachers $[18,19]$. The drawback of this chain is the fact that the practitioners stopped once they obtained answers for the questions without asking additional follow-up questions to learn in-depth information. It was realized that pre-service teachers often asked questions mostly seeking for clarification of definitions provided. In fact, in the context of argument-based learning environments, it is essential that questions are asked for particular purpose of giving justifications and students justify their arguments to defend them against the other arguments. In this way, valid and high quality arguments can be proposed. The obtained data reveal that only a small proportion of pre-service teachers referred to such questions for justifications. A large part of the groups asking such questions were seen to carry out the whole practice by using "why" and "how" questions only. Though such questions partly help explain the grounds for justification, it could be more appropriate to express more clearly the questions which will help uncover the justifications. In the light of the study data, it seems that practicing pre-service teachers did not perform well enough in creating rich discussion or managing the discussion environment skillfully.

It is essential that teachers need to acquire professional efficiency in this domain. Because, it is unreasonable to expect science teachers to be able to participate in scientific argumentation or understand how the nature of scientific argumentation and arguments differ from what often takes place in other contexts if they have never had a chance to learn about this complex practice [17]. So, various courses to improve pre-service teachers' skills and knowledge in this domain could be included in curriculum as compulsory or elective courses. Moreover, it could be useful to revise common compulsory courses of education at the undergraduate level so that pre-service teachers can develop their skills and perform practices in relation with these skills.

\section{REFERENCES}

[1] Crowell, A. (2011). Assessment of three year argument skills development curriculum. Unpublished doctoral dissertation, Columbia University.

[2] Sadler, T. D. (2004). Informal reasoning regarding socioscientific issues: A critical review of research. Journal of Research in Science Teaching, 41(5), 513-536.

[3] Sampson, V., \& Clark, D. (2009). The impact of collaboration on the outcomes of scientific argumentation. Science Education, 93(3), 448-484.

[4] NRC. (2011). A Framework for K-12 Science Education:
Practices, Crosscutting Concepts, and Core Ideas. In N. R. Council (Ed.). Washington, D.C.: National Academies Press.

[5] Boyer, E. C. (2012). Preservice elementary teachers' use of a discursive model of meaning making in the co-construction of science understanding. Unpublished doctoral dissertation, The Pennsylvania State University.

[6] Viiri, J., \& Saari, H. (2006). Teacher talk patterns in science lessons: Use in teacher education. Journal of Science Teacher Education, 17, 347-365.

[7] McNeill, K., \& Krajcik, J. (2008). Scientific explanations: Characterizing and evaluating the effects of teachers' instructional practices on student learning. Journal of Research in Science Teaching, 45(1), 53-78.

[8] Berland, L., \& Reiser, B. (2009). Making sense of argumentation and explanation. Science Education, 93(1), 26-55.

[9] Osborne, J., Erduran, S., \& Simon, S. (2004). Enhancing the quality of argumentation in science classrooms. Journal of Research in Science Teaching, 41(10), 994-1020.

[10] Duschl, R., \& Osborne, J. (2002). Supporting and Promoting argumentation discourse in science education. Studies in Science Education, 18, 39-72.

[11] Haefner, L. A., \& Zembal-Saul, C. (2004). Learning by doing? Prospective elementary teachers' developing understanding of scientific inquiry and science teaching and learning. International Journal of Science Education, 26(13), $1653-1674$

[12] Zembal-Saul, C. (2009). Learning to teach elementary school science as argument. Science Education, 93, 687-719.

[13] Turkish Language Association (2015) Great Turkish Dictionary (http://tdk.gov.tr/index.php?option=com_bts\&view=bts)

[14] Harlow, D. \& Otero, V. (2004). An examination of children's scientific argumentation. Physics Education Research Conference Proceedings. V. 720, 145-148

[15] Roth, K.J., Druker, S.L., Garnier, H., Lemmens, M., Chen, C., Kawanaka, T., Rasmussen, D., Trubacova, S., Warvi, D., Okamoto, Y., Gonzales, P., Stigler, J., \& Gallimore, R. (2006). Teaching science in five countries: Results from the TIMSS 1999 video study. Washington, DC: National Center for Education Statistics.

[16] Newton, P., Driver, R., \& Osborne, J. (1999). The place of argumentation in the pedagogy of school science. International Journal of Science Education, 21(5), 553-576.

[17] Sampson, V. \& Blanchard, M.R, (2012). Science teachers and scientific argumentation: trend an views and practice. Journal of Research in Science Education, 49(9), 1122-1148.

[18] McNeill, K. L., \& Pimentel, D. S. (2010). Scientific discourse in three urban classrooms: The role of the teacher in engaging high school students in argumentation. Science Education, 94(2), 203-229.

[19] Xie, Q. \& So, W.W.M., (2012). Understanding and practise of argumentation: a pilot study with Mainland Chinese pre-service teachers in secondary science teachers. Asia-Pasific Forum on Science Learning an Teaching, 12(2), Article 9.

\footnotetext{
This paper was presented as a platform presentation at the World Conference on Learning, Teaching \& Educational Leadership, October 29-31, 2015, Paris, France
} 